\title{
A Human-Type Nonalcoholic Steatohepatitis Model with Advanced Fibrosis in Rabbits
}

\author{
Tomohiro Ogawa, ${ }^{*}$ Hideki Fujii, ${ }^{*}$ \\ Katsutoshi Yoshizato, ${ }^{* \dagger}$ and Norifumi Kawada* \\ From the Department of Hepatology,* Graduate School of \\ Medicine, Osaka City University, Osaka; and PhoenixBio Co. \\ Ltd. ${ }^{\dagger}$ Hiroshima, Japan
}

Nonalcoholic steatohepatitis (NASH) progresses to liver fibrosis and cirrhosis, which can lead to lifethreatening liver failure and the development of hepatocellular carcinoma. The aim of the present study was to create a rabbit model of NASH with advanced fibrosis (almost cirrhosis) by feeding the animals a diet supplemented with $0.75 \%$ cholesterol and $12 \%$ corn oil. After 9 months of feeding with this diet, the rabbits showed high total cholesterol levels in serum and liver tissues in the absence of insulin resistance. The livers became whitish and nodular. In addition, the number of rabbit macrophage antigen-positive cells and the expression of mRNAs for inflammatory cytokines showed a significant increase. Moreover, fibrotic septa composed of collagens and $\alpha$-smooth muscle actin-positive cells were found between the central and portal veins, indicating alteration of the parenchymal architecture. There was also a marked increase of mRNAs for transforming growth factor- $\beta 1$ and collagen 1A1. Comprehensive analysis of protein and gene expression revealed an imbalance of the antioxidant system and methionine metabolism. We also found that ezetimibe attenuated steatohepatitis in this model. In conclusion, the present rabbit model of NASH features advanced fibrosis that is close to cirrhosis and may be useful for analyzing the molecular mechanisms of human NASH. Ezetimibe blunted the development of NASH in this model, suggesting its potential clinical usefulness for human steatohepatitis. (Am J Patbol 2010, 177:153-165; DOI: 10.2353/ajpath.2010.090895)

A high-fat diet is one of the risk factors for metabolic syndrome, which is characterized by obesity, hyperlipidemia, hyperglycemia, and hypertension, and is frequently accompanied by life-threatening arteriosclerosis. ${ }^{1} \mathrm{~A}$ high-calorie, high-fat diet is also considered to cause nonalcoholic fatty liver disease (NAFLD), which covers a spectrum of disorders from simple steatosis to nonalcoholic steatohepatitis (NASH) and cirrhosis. ${ }^{2-5}$ Recent clinical studies have shown that NAFLD is one of the common liver diseases that leads to cirrhosis and hepatocellular carcinoma ${ }^{2}$ in a manner similar to the clinical course of chronic viral hepatitis and alcohol abuse. ${ }^{6}$ However, the molecular mechanisms underlying the progression of NAFLD to an advanced stage with active inflammation and fibrosis are not fully understood. We recently reported a rabbit model of steatohepatitis that was generated by feeding the rabbit a high-fat and -cholesterol diet (HFD) supplemented with $20 \%$ corn oil and $1.25 \%(w / w)$ cholesterol for 8 weeks. ${ }^{7}$ The rabbit showed insulin resistance, accumulation of lipids in hepatocytes, activation of Kupffer cells (liver macrophages), mild fibrosis, and enhanced oxidative stress. Thus, we concluded that this model was useful for analyzing the molecular mechanisms involved in the pathogenesis of human $\mathrm{NASH}$. However, rabbits fed a HFD have a short lifespan attributable to heart failure accompanied by severe arteriosclerosis. ${ }^{8}$ This makes it difficult to study whether advanced fibrosis or even cirrhosis can be caused solely by HFD feeding. We therefore tried to improve the model and produce NASH with advanced fibrosis, which is more similar to the disease observed in humans that gradually develops after several decades. In the present study, this was accomplished by reducing the concentrations of cholesterol and corn oil in the diet and by prolonging the feeding period from 2 to 9 months.

Supported by the Japan Society for the Promotion of Science (grant-in-aid for scientific research 18659214, 2007, to N.K.) and by a Thrust Area research grant from Osaka City University (2008) (N.K.).

Accepted for publication March 22, 2010.

Portions of this study were presented in abstract form at the 44th Annual Meeting of the European Association for the Study of the Liver, Copenhagen, 2009.

CME Disclosure: None of the authors disclosed any relevant financial relationships.

Supplemental material for this article can be found on http://ajp. amjpathol.org.

Address reprint requests to Norifumi Kawada, M.D., Ph.D., Department of Hepatology, Graduate School of Medicine, Osaka City University, 1-4-3, Asahimachi, Abeno, Osaka 545-8585, Japan. E-mail: kawadanori@ med.osaka-cu.ac.jp. 
NAFLD/NASH is assumed to be most effectively improved by weight control and by restricting lipid and calorie intake, thereby leading to normalized lipid metabolism. ${ }^{9,10}$ Nevertheless, drug therapy would be a useful and an easy option because the modern lifestyle habits such as poor diet and lack of regular exercise are difficult to change. Ezetimibe is a relatively new and promising drug candidate for NAFLD/NASH therapy. Ezetimibe selectively inhibits cholesterol absorption via Niemann-Pick C1-like 1 (NPC1L1) protein in the brush border of the small intestine in humans, rodents, rabbits, and other species. ${ }^{11-15}$ It decreases the serum levels of low-density lipoprotein cholesterol and triglycerides (TGs) in humans ${ }^{16}$ and reduces plaque formation and improves lipids in a rabbit model of atherosclerosis. ${ }^{17}$ Recent reports have indicated that ezetimibe improves liver steatosis and insulin resistance in Zucker obese fatty rats $^{18}$ and rats fed a methionine- and choline-deficient diet. ${ }^{19}$ Thus, ezetimibe is a potential new therapeutic agent for human $\mathrm{NASH} .{ }^{20}$ In the present study, we also assessed the effect of ezetimibe on the development of $\mathrm{NASH}$ in our rabbit model.

\section{Materials and Methods}

\section{Materials}

Mouse monoclonal antibodies against $\alpha$-smooth muscle actin $(\alpha S M A)$, rabbit macrophage (clone RAM-11), and 4-hydroxy-2-nonenal (4-HNE) were obtained from Sigma Chemical Co. (St. Louis, MO), Thermo Fisher Scientific (Fremont, CA), and Nikken Seil Co., Ltd. (Shizuoka, Japan), respectively. Enhanced chemiluminescence detection reagent was obtained from Amersham Pharmacia Biotech (Little Chalfont, Buckinghamshire, UK), and Immobilon-P membranes were from Millipore Corp. (Bedford, MA). All other reagents were purchased from Sigma Chemical Co. or Wako Pure Chemical Co. (Osaka, Japan).

\section{Animals and Experimental Protocol}

Pathogen-free male Japanese White rabbits, about 1-year-old and weighing 3.0 to $3.5 \mathrm{~kg}$, were obtained from SLC (Shizuoka, Japan). As shown in Figure 1, we performed the following two experiments: i) rabbits were housed at a constant temperature and were given either $100 \mathrm{~g} /$ day of a standard diet (SD) $(n=5$, CR3 obtained from CLEA Japan Inc., Tokyo, Japan) or version II of an improved high-fat and -cholesterol diet (HFD II) $(n=5)$, which consisted of SD supplemented with $12 \%$ corn oil and $0.75 \%$ (w/w) cholesterol for 9 months; and ii) rabbits were given version I (100 g/day) of a previously reported HFD (HFD I), which consisted of SD supplemented with $20 \%$ corn oil and $1.25 \%$ (w/w) cholesterol for 2 months. $^{7}$ The treated group additionally received $0.6 \mathrm{mg} / \mathrm{kg} /$ day of ezetimibe mixed in the diet. Ezetimibe was kindly provided by Bayer AG (Leverkusen, Germany). The contents of the SD and HFD I and II are shown in Supplemental Table S1 (see http://ajp.amjpathol.org).

\section{Experiment 1 (NASH cirrhosis model):}

SD (Standard diet)

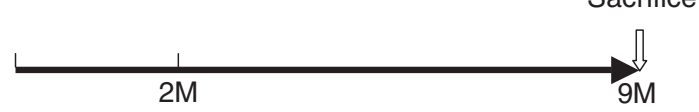

HFD II $(0.75 \%$ cholesterol $/ 12 \%$ corn oil-contained diet)

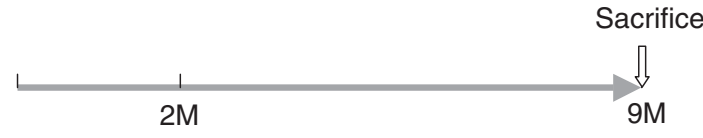

\section{Experiment 2 (NASH therapy model):}

HFD I (1.25\% cholesterol/20\% corn oil-contained diet) Sacrifice

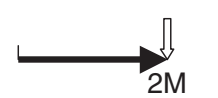

HFD I plus Ezetimibe $(0.6 \mathrm{mg} / \mathrm{kg} /$ day $)$ Sacrifice

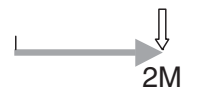

Figure 1. Experimental schedule of the present study. Experiment 1: NASH cirrhosis was induced in rabbits by feeding HFD II for nine months. Experiment 2: during NASH therapy, rabbits were administrated ezetimibe (0.6 $\mathrm{mg} / \mathrm{kg} /$ day) supplemented with HFD I for two months. In the NASH therapy model, a previously reported HFD I was used to evaluate the effect of medicine during a short period.

The rabbits were fasted 24 hours before sacrifice. Then they were anesthetized and laparotomized for blood and liver sampling. The portal vein was cannulated using an 18-gauge Teflon catheter. The liver of each animal was perfused with $100 \mathrm{ml}$ of PBS to remove the blood. After harvest, the liver was cut into small pieces and fixed in 4\% paraformaldehyde. Each sample was either frozen or embedded in paraffin. The experiments were conducted humanely in accordance with the recommendations of the Guide for the Care and Use of Laboratory Animals of Osaka City University School of Medicine.

\section{Histochemical and Immunohistochemical Studies}

Paraformaldehyde-fixed specimens were sectioned into 5 - $\mu \mathrm{m}$-thick sections and stained with H\&E and $0.1 \%$ (w/v) Sirius red (Direct Red 80, Aldrich, Milwaukee, WI). Frozen sections (5- $\mu \mathrm{m}$-thick) were stained with Oil red $\mathrm{O}$ (Wako Pure Chemical Co.). The areas stained by Sirius red and Oil red $\mathrm{O}$ were measured to assess the areas of connective tissue and lipid deposition, respectively, using an image analyzer (Lumina Vision, Mitani Corporation, Tokyo, Japan).

Immunohistochemical analysis was performed as described elsewhere. ${ }^{7}$ In brief, sections were deparaffinized, washed, and preincubated in 5\% bovine serum albumin blocking solution, followed by overnight incubation at $4^{\circ} \mathrm{C}$ with antibodies against either $\alpha \mathrm{SMA}$ at a dilution of $1: 100$, rabbit macrophage $(\mathrm{RAM}-11)^{21}$ at a dilution of $1: 100$, or $4-\mathrm{HNE}$ at a concentration of $5 \mu \mathrm{g} /$ $\mathrm{ml} .^{22}$ The sections were incubated with biotinylated sec- 
ondary antibodies and reacted with horseradish peroxidase-conjugated streptavidin (Nichirei Biosciences Inc., Tokyo, Japan) and then treated with diaminobenzidine (DAKO, Glostrup, Denmark) for color development.

\section{Laboratory Tests}

Serum levels of aspartate aminotransferase (AST), alanine aminotransferase (ALT), total cholesterol (T-Cho), $T G$, free fatty acid (FFA), and fasting glucose were measured at the Special Reference Laboratories (Osaka, Japan). Fractionation of serum cholesterol was performed by high-performance liquid chromatography at Skylight Biotech (Akita, Japan). The serum and urine levels of oxidative stress markers and antioxidants were measured at Nikken Seil Co., Ltd. Fasting serum insulin levels were measured using a rat insulin enzyme-linked immunosorbent assay kit and a rabbit insulin standard solution (Shibayagi Co. Ltd., Gunma, Japan). Homeostasis model assessment of insulin resistance (HOMA-IR) was calculated using the formula HOMA-IR = [fasting insulin (ng/ $\mathrm{ml}) \times 23.1] \times$ fasting glucose $(\mathrm{mg} / \mathrm{dl}) / 405$. Serum bile acid was measured using a Total Bile Acids Test Wako (Wako Pure Chemical Co.) according to the manufacturer's instructions.

\section{Assay of Hepatic Total Cholesterol, Triglyceride, and Free Fatty Acid Levels}

Liver tissue (50 to $100 \mathrm{mg}$ ) was homogenized in $0.75 \mathrm{ml}$ of methanol and chloroform (2:1), and lipids were extracted from the chloroform fraction. Then, the hepatic tissue levels of T-Cho and TG were determined using a Cholesterol E-Test Wako and Triglyceride E-Test Wako (Wako Pure Chemical Co.) according to the manufacturer's instructions. The data were expressed as the amount of T-Cho (mg) or TG (mg)/liver wet weight $(\mathrm{g})$.

For the hepatic FFA assay, liver tissue $(10 \mathrm{mg}$ ) was homogenized in $0.2 \mathrm{ml}$ of chloroform and $1 \%$ Triton $X-100$. Fatty acids were extracted in the chloroform fraction and air-dried to remove the chloroform. Then, the hepatic tissue FFA levels were determined using a Free Fatty Acid Quantification Kit (BioVision, Mountain View, $\mathrm{CA}$ ) according to the manufacturer's instructions. The data were expressed as the amount of FFA (nmol)/liver wet weight $(\mathrm{mg})$.

\section{Quantitative Real-Time PCR}

Total RNA was extracted from the liver using Isogen (Nippon Gene Co. Ltd., Tokyo, Japan). cDNAs were synthesized with $1 \mu \mathrm{g}$ of total RNA, ReverTra Ace (Toyobo, Osaka, Japan), and oligo(dT) ${ }_{12-18}$ primers according to the manufacturer's instructions. ${ }^{23}$ Gene expression was measured by real-time PCR on an Applied Biosystems Prism 7500 system (Applied Biosystems, Foster City, CA) using CDNA, real-time PCR Master Mix Reagents (Toyobo), a set of gene-specific oligonucleotide primers, and the TaqMan probes listed in Table 1.

\section{Immunoblotting}

Protein samples $(10 \mu \mathrm{g})$ were subjected to SDS-polyacrylamide gel electrophoresis (PAGE) and then transferred to Immobilon-P membranes. After blocking, the membranes were treated with the primary antibodies and then with horseradish peroxidase-conjugated secondary antibodies. Immunoreactive bands were visualized using the enhanced chemiluminescence system and documented with LAS 1000 (Fuji Photo Film, Kanagawa, Japan). The density of each band was analyzed using a GS-700 densitometer (Bio-Rad Laboratories, Hercules, CA). ${ }^{23}$

\section{Assay of Hepatic 8-Hydroxy-2'-Deoxyguanosine Levels}

Liver tissue (100 to 200 mg) was homogenized in lysis buffer, and hepatic DNA was extracted using the DNA Extractor TIS kit (Wako Pure Chemical Co.). After the DNA was hydrolyzed, 8-hydroxy-2'-deoxyguanosine levels in the liver were measured using a highly sensitive 8-hydroxy-2'-deoxyguanosine enzyme-linked immunosorbent assay kit (Nikken Seil Co. Ltd.) according to the manufacturer's instructions.

\section{Proteome Analysis}

Two-dimensional SDS-PAGE was performed by Towa Environment Science (Osaka, Japan). ${ }^{24}$ Proteins (100 $\left.\mu \mathrm{g}\right)$ extracted from rabbit livers were applied to Immobiline DryStrips ( $\mathrm{pH} 3$ to 10). After isoelectric focusing, the proteins were separated by SDS-PAGE on 9 to 18 acrylamide gradient gels, visualized by SYPRO Ruby staining, scanned, and analyzed as described previously. ${ }^{25}$ Protein spots of interest were excised from the gels, digested in trypsin solution, dialyzed, and then analyzed by electrospray ionization mass spectrometry. The proteins were identified from the obtained amino acid sequences using databases such as protein BLAST or FASTA.

\section{Microarray Analysis}

Total RNA was extracted from liver tissues with Isogen. Rabbit microarray chips were designed on the eArray system (Agilent Technologies, Palo Alto, CA) and were provided by Takara Bio Inc. (Shiga, Japan). The gene expression profile of HFD II-fed rabbits was compared with that of SD-fed rabbits. Genes showing differences in expression with an increase of more than fivefold or a decrease to $<0.5$-fold were recognized as up- or downregulated genes, respectively, and were targeted for further analysis. The data are partially shown in Supplemental Table S2 (see http://ajp.amjpathol.org).

\section{Statistical Analysis}

Bar graphs present data as means \pm SD of at least three independent experiments. Statistical analysis was per- 
Table 1. List of Primer Sequences

\begin{tabular}{|c|c|c|}
\hline Gene & Sequence & Accession no. \\
\hline \multicolumn{3}{|l|}{ PPAR } \\
\hline Forward & 5'-CCTGGCTTTGTGAGCCTTGAC-3' & \multirow[t]{2}{*}{ AY166780 } \\
\hline Reverse & 5'-GAGGCCAGCATGGTGTAGATGA-3' & \\
\hline \multicolumn{3}{|c|}{ 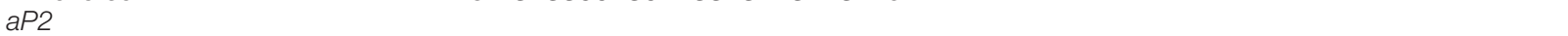 } \\
\hline Forward & $5^{\prime}$-CAGATGACAGGAAAGGCAAGAGT-3' & \multirow[t]{2}{*}{ AF136241 } \\
\hline Reverse & 5'-CCTCCCGTTTTCTCTTTATGGT-3' & \\
\hline \multicolumn{3}{|c|}{ 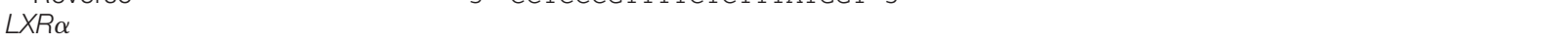 } \\
\hline Forward & 5'-GGAGACGTCTCGCAGGTACA-3' & \\
\hline Reverse & $5^{\prime}$-CCCTGCTTTGGCAAAGTCCT-3' & \\
\hline \multicolumn{3}{|l|}{ SREBP1 } \\
\hline Forward & $5^{\prime}-$ GACACAGGAGCCACAATGAAGAC-3' & \multirow[t]{2}{*}{ AF278696 } \\
\hline Reverse & 5'-GCAGTTTGTCTGTGTCCACAACC-3' & \\
\hline \multicolumn{3}{|c|}{ 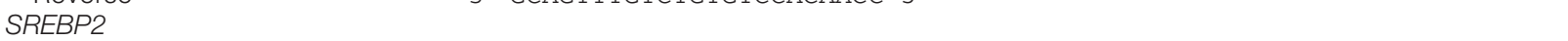 } \\
\hline Forward & $5^{\prime}$-GGCGGACAAGACACAATATCA-3' & \multirow[t]{5}{*}{ AF278693 } \\
\hline Reverse & 5'-GTCCCCATGACCAAGTCTTTCA-3' & \\
\hline HMGCR & & \\
\hline Forward & 5'-TGCTGTGAGAACGTGATTGGG-3' & \\
\hline Reverse & 5'-CTTTCCATCCAAGCAGAGAGGT-3' & \\
\hline \multicolumn{3}{|c|}{ S - IIILCAILCAAGLAGAGAGGI-J } \\
\hline Forward & $5^{\prime}-\mathrm{ACAACCCGGTCTACCAGAAG-3^{ \prime }}$ & \multirow[t]{2}{*}{ M11501 } \\
\hline Reverse & 5'-ATCTGTCTCGAGGGGTAGGT-3' & \\
\hline \multicolumn{3}{|l|}{ CYP7A1 } \\
\hline Forward & 5'-CGATGCCTTGATTTCCCTCACAG-3' & \multirow[t]{2}{*}{ NM_001170929 } \\
\hline Reverse & 5'-TTGGTTCAGGACGTCTCAAGGTAAG-3' & \\
\hline G6Pase & & \\
\hline Forward & 5'-GCAGGTGTGTACTACGTGATGGT-3' & EU520488 \\
\hline Reverse & $5^{\prime}$-GTCAAGCACCGAAATCTGTAGGTC-3' & \\
\hline PEPCK & & \\
\hline Forward & 5'-CACATCCCAАCTCTCGCTTCTG-3' & EF616471 \\
\hline Reverse & 5'-TCCAAAGATGATGGCATCAATGGG-3' & \\
\hline$T N F \alpha$ & & \\
\hline Forward & 5'-GTCACCCTCAGATCAGCTTCTC-3' & NM_001082263 \\
\hline Reverse & $5^{\prime}-$ GTTCGCACGCTGGCTCAG- $3^{\prime}$ & \\
\hline Probe & 5'-CCTGAGTGACAAGCCTCTAGCCCACG-3' & \\
\hline$I L-1 \beta$ & & \\
\hline Forward & 5'-GCCTGAGAACTTTCTTTTCCTTAATC-3' & M26295 \\
\hline Reverse & $5^{\prime}$ - GATCGTACTGCATCACACTCAAG-3' & \\
\hline Probe & $5^{\prime}$-AAGAACCCGTCCTCTGCAACACCTGG-3' & \\
\hline IL-10 & & \\
\hline Forward & 5'-CCTTGTCGGAGATGATCCAGTT-3' & DQ437508 \\
\hline Reverse & $5^{\prime}$-ATGGCTGGACTGTGGTTCTCA-3' & \\
\hline IL-18 & & \\
\hline Forward & 5'-GCAACCTGTGTTTGAGGATATGC-3' & NM_001122940 \\
\hline Reverse & 5'-CCATGCCTCTAGTATTGCTGTCTT-3' & \\
\hline TLR2 & & \\
\hline Forward & 5'-TCTGCACAAGCGGGACTTT-3' & NM_001082781 \\
\hline Reverse & 5'-TTCTCGATGCAGTCGATGATGT-3' & \\
\hline TLR4 & & \\
\hline Forward & $5^{\prime}$-AGCCATGCGGGTATCATTTT-3' & NM_001082732 \\
\hline Reverse & 5' -TCCTGCTGAGAAGGCGATACA-3' & \\
\hline CD14 & & \\
\hline Forward & 5'-GCGCTAAACTCCCTCAATCTATC-3' & M90488 \\
\hline Reverse & 5'-GCCCTATTCAGCTTGTTGCA-3' & \\
\hline MD2 & & \\
\hline Forward & 5'-GAAGGGAGAGACTGTGAATACAACAG-3' & NM_001082787 \\
\hline Reverse & $5^{\prime}$-GCTATGGCTTCTACAACACATCTG-3' & \\
\hline $\mathrm{HO}-1$ & & \\
\hline Forward & 5'-GGAGAACGCCGAGTTCATGA-3' & AY421756 \\
\hline Reverse & 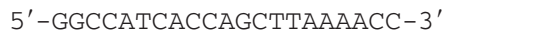 & \\
\hline Probe & 5'-AACTTTCAGAAGGGCCAGGTGACTGCC-3' & \\
\hline TGF $\beta 1$ & & \\
\hline Forward & $5^{\prime}$-AAGGGCTACCACGCCAACTT-3' & AF000133 \\
\hline Reverse & 5' -CGGGTTGTGCTGGTTGTACA-3' & \\
\hline Probe & 5'-TGCCTGGGACCCTGCCCCTAC-3' & \\
\hline Col1A1 & & \\
\hline Forward & $5^{\prime}-$ ACTGGATTGACCCCAACCA-3' & AY633663 \\
\hline Reverse & $5^{\prime}-$ TTGCCCCAGTGTCCATGTC- $3^{\prime}$ & \\
\hline Probe & $5^{\prime}$-CTGCAACCTGGATGCCATCAAGGTC-3' & \\
\hline & & (table continues) \\
\hline
\end{tabular}


Table 1. Continued

\begin{tabular}{|c|c|c|}
\hline Gene & Sequence & Accession no. \\
\hline \multicolumn{3}{|l|}{ Col3A1 } \\
\hline Forward & 5'-CATTGGCCCTGTTTGCTTTT-3' & \multirow[t]{2}{*}{ S83371 } \\
\hline Reverse & 5'-GTTGGTCACTTGTACTGGTTGACA-3' & \\
\hline \multicolumn{3}{|c|}{ (2) } \\
\hline Forward & $5^{\prime}-$ TCACTCCTGAGATCTGCACACA-3' & \multirow[t]{2}{*}{ NM_001082209 } \\
\hline Reverse & 5'-CAAATGAACCGGTCCTTGAAG-3' & \\
\hline \multicolumn{3}{|c|}{ 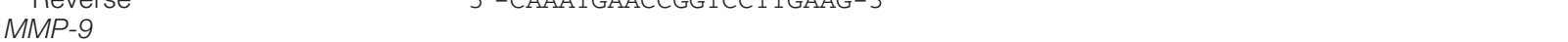 } \\
\hline Forward & 5'-GCTCCGGTGGATCAGATGTT-3' & \multirow[t]{3}{*}{ NM_001082203 } \\
\hline Reverse & $5^{\prime}-$ AAGCGGTCCTGGCAGAAGT-3' & \\
\hline Probe & 5'-CACACGACGTCTTCCAGTACCGAGAG-3' & \\
\hline \multicolumn{3}{|l|}{ TIMP-1 } \\
\hline Forward & 5'-TGGAAAGTGTCTGCGGGTACT-3' & \multirow[t]{2}{*}{ AY829730 } \\
\hline Reverse & 5' -TTGTCCAGCGATGAGAAACTC-3' & \\
\hline \multicolumn{3}{|c|}{ 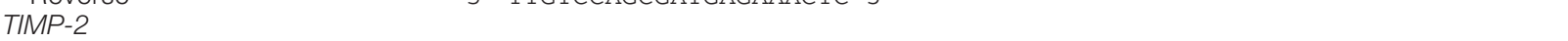 } \\
\hline Forward & 5'-TCACGCTCTGTGACTTCATCGT-3' & \multirow[t]{3}{*}{ AF069713 } \\
\hline Reverse & 5'-TGTGGTTCAGGCTCTTCTTCTG-3' & \\
\hline Probe & $5^{\prime}$-СССTGGGACTCCCTGAGCAGCA-3' & \\
\hline \multicolumn{3}{|l|}{ GPO } \\
\hline Forward & 5'-AAGGTGCTGCTCATTGAGAATG-3' & \multirow[t]{2}{*}{ NM_001085444 } \\
\hline Reverse & 5'-TTCTCCTGATGCCCAAACTG-3' & \\
\hline \multicolumn{3}{|c|}{ 5-TICTCCTGATGCLCAAACTG-3 } \\
\hline Forward & 5'-CAAGTGGCTGAGTGAGAAGTTCA-3' & \multirow[t]{2}{*}{ NM_001082252 } \\
\hline Reverse & 5'-TTGCTCTGCGTGAGCTTGT-3' & \\
\hline \multirow{2}{*}{\multicolumn{3}{|c|}{$\mathrm{Cu}, \mathrm{Zn}-$}} \\
\hline & & \\
\hline Forward & 5'-TGGTGGTCCACGAGAAAGAAG-3' & \multirow[t]{2}{*}{ L12405 } \\
\hline Reverse & 5'-CGTTCCCGGTCTTTGTACTCT-3' & \\
\hline \multicolumn{3}{|c|}{ S -CGILCLGGICIIIGIACILI-3 } \\
\hline Forward & 5'-ATTGCTGCGTGTGCGAATC-3' & \multirow[t]{2}{*}{ L28808 } \\
\hline Reverse & $5^{\prime}-$ TCAATCCCCAGCAGTGGAA-3' & \\
\hline \multicolumn{3}{|c|}{ - } \\
\hline Forward & 5'-TCCACCTGGACAGAAACGAAGAGGA-3' & \\
\hline Reverse & 5'-TCTCGTCAGTGGCATAGCCGAACA-3' & \\
\hline \multicolumn{3}{|c|}{ 5 -ICICGICAGIGGLATAGLCGAACA-3 } \\
\hline Forward & 5'-AGGGCTTCAGTGTGACGAGTGT-3' & \multirow[t]{2}{*}{ D13307 } \\
\hline Reverse & 5'-CGGTTCCAGCGCTCTTTAA-3' & \\
\hline \multicolumn{3}{|l|}{ ST3A1 } \\
\hline Forward & 5'-GTGCCCTTCTTGGAATACAACA-3' & \multirow[t]{2}{*}{ NM_001082210 } \\
\hline Reverse & $5^{\prime}-$ TGGAAGGTGGGAAGCAAAG-3' & \\
\hline \multicolumn{3}{|c|}{ S IGGAAGGIGGGAAGLAFAG } \\
\hline Forward & $5^{\prime}$-GCCAAAAGGGTCATCATCTCA-3' & \multirow[t]{3}{*}{ AB231852 } \\
\hline Reverse & 5'-GTGGTTCACGCCCATCACA-3' & \\
\hline Probe & $5^{\prime}-$ CCTCCGCCGATGCCCCCA-3' & \\
\hline
\end{tabular}

formed with Student's $t$-test, and differences were considered significant at $P<0.05$.

\section{Results}

\section{Hepatic Lipid Deposition in Rabbits Fed High-Fat and -Cholesterol Diet II}

Rabbits fed HFD I for 2 months exhibited insulin resistance, hepatic steatosis, inflammation, oxidative stress, and mild fibrosis, thus, showing similarity to human NASH as we reported previously. ${ }^{7}$ After the feeding period was increased by reducing the fat and cholesterol content in the diet to $60 \%$ of the previous level (HFD II) to prolong rabbit survival, we were able to create a model with advanced hepatic fibrosis that was close to cirrhosis. As shown in Table 2, serum T-Cho and TG levels of rabbits fed HFD II for 9 months increased significantly compared with the levels in rabbits fed SD. The serum cholesterol was mainly very low-density lipoprotein and lipoprotein cholesterol according to the high-performance liquid chromatography analysis. However, serum AST and ALT levels in HFD II-fed rabbits did not change significantly compared with those in SD-fed rabbits. Fasting glucose and insulin values in HFD II-fed rabbits were lower than those in SD-fed rabbits, and HOMA-IR was reduced in HFD-fed rabbits.

The livers of HFD II-fed rabbits were enlarged and whitish with an irregular, partially nodular surface (Figure 2, A and B), showing an appearance that was totally different from the livers of SD-fed rabbits. H\&E staining indicated degeneration of hepatocytes predominantly around the central vein area (Figure 2, C and D). At a higher magnification, H\&E staining also revealed glassy degeneration of hepatocytes, which was similar to the ballooning of hepatocytes in human NASH, fibrosis, and bile duct proliferation (Figure 2, E and F), as well as atheroma in the aorta (Figure 2, G and H). The hepatocytes were strongly positive for $\mathrm{Oil}$ red $\mathrm{O}$ staining (Figure 3, A and B), Furthermore, hepatic T-Cho content in- 
Table 2. Liver Enzymes and Lipid Profile in Serum

\begin{tabular}{|c|c|c|c|}
\hline Enzymes/lipids & SD & HFD ॥ & $P$ value \\
\hline AST (IU/L) & $43.4 \pm 29.9$ & $29.3 \pm 22.4$ & NS \\
\hline ALT (IU/L) & $45.6 \pm 36.6$ & $19.7 \pm 18.2$ & NS \\
\hline \multicolumn{4}{|l|}{ Cholesterol (mg/dl) } \\
\hline Total & $19.2 \pm 3.8$ & $1161.3 \pm 406.5$ & $P<0.01$ \\
\hline Chylomicron & $0.2 \pm 0.2$ & $159.6 \pm 161.8$ & NS \\
\hline Very low-density lipoprotein & $1.7 \pm 0.6$ & $733.0 \pm 294.6$ & $P<0.01$ \\
\hline Low-density lipoprotein & $2.7 \pm 0.8$ & $241.6 \pm 74.5$ & $P<0.01$ \\
\hline High-density lipoprotein & $14.6 \pm 4.2$ & $27.1 \pm 12.5$ & NS \\
\hline $\mathrm{TG}(\mathrm{mg} / \mathrm{dl})$ & $26.7 \pm 11.9$ & $205.5 \pm 96.3$ & $P<0.01$ \\
\hline $\mathrm{FFA}(\mu \mathrm{Eq} / \mathrm{L})$ & $279.7 \pm 150.7$ & $168.4 \pm 107.9$ & NS \\
\hline Fasting glucose (mg/dl) & $132.7 \pm 11.0$ & $98.4 \pm 47.3$ & $P<0.05$ \\
\hline Fasting insulin ( $\mathrm{ng} / \mathrm{ml})$ & $1.1 \pm 0.2$ & $0.7 \pm 0.2$ & $P<0.05$ \\
\hline HOMA-IR & $8.4 \pm 2.3$ & $5.2 \pm 2.6$ & $P<0.05$ \\
\hline Bile acid & $5.3 \pm 1.3$ & $33.7 \pm 17.4$ & $P<0.05$ \\
\hline
\end{tabular}

\footnotetext{
NS, not significant.
}

creased significantly in HFD II-fed rabbits $(38.3 \pm 21.5$ $\mu \mathrm{g} / \mathrm{mg}$ liver weight) compared with that in SD-fed rabbits (1.5 $\pm 0.2 \mu \mathrm{g} / \mathrm{mg}$ liver weight), although the hepatic TG and FFA contents were similar (Figure $3 \mathrm{C}$ ), indicating that
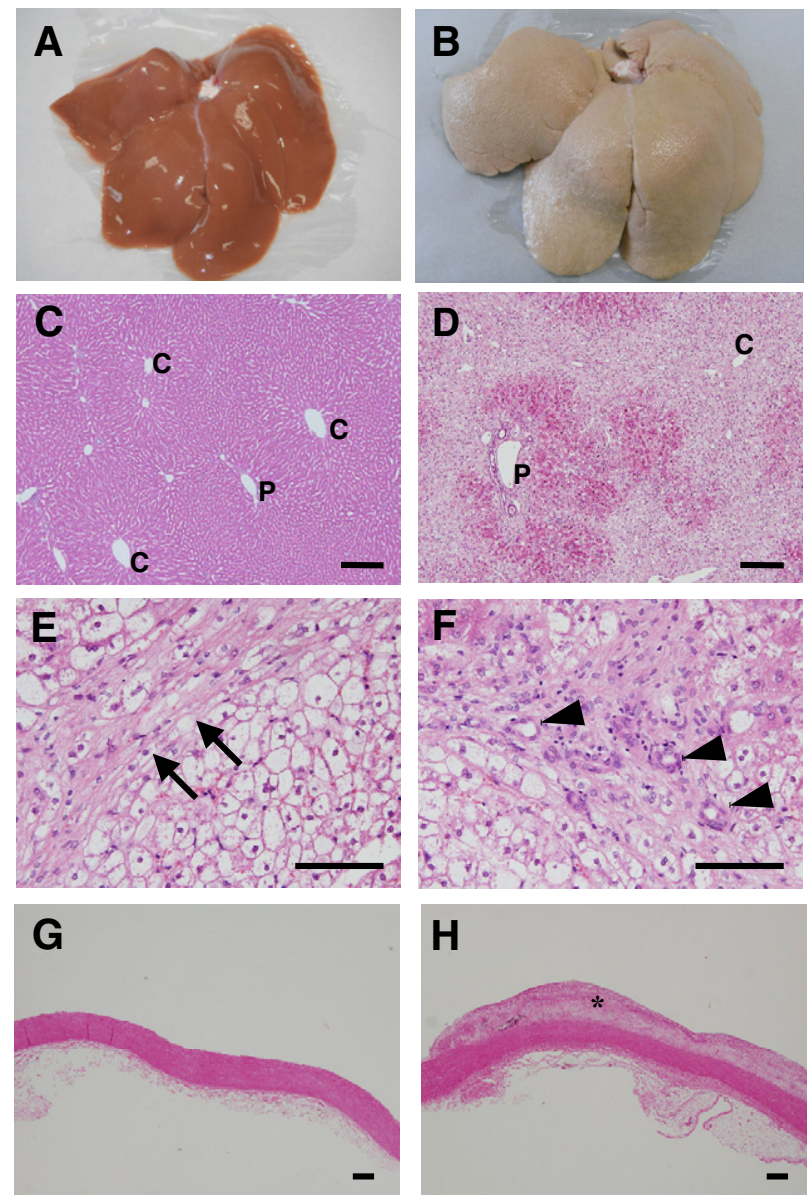

Figure 2. Steatosis and fibrosis in the liver of HFD II-fed rabbits. Rabbits were fed SD (A, C, and $\mathbf{G})$ or HFD II (B, D, E, F, and $\mathbf{H})$ for nine months. $\mathbf{A}$ and $\mathbf{B}$ : Macroscopic appearance of the livers of SD- and HFD II-fed rabbits. C-H: H\&E staining of the liver $(\mathbf{C}-\mathbf{F})$ and aorta $(\mathbf{G}$ and $\mathbf{H})$. Note that lipid-induced hepatic degeneration and liver fibrosis are predominantly seen in the livers (D-F) and that atheroma developed in the aorta $(\mathbf{H})$ of HFD II-fed rabbits. Arrows in $\mathbf{E}$ arrowheads in $\mathbf{F}$ and asterisk in $\mathbf{H}$ indicate fibrotic septa, bile duct proliferation, and atheroma, respectively. P, portal vein; $\mathrm{C}$, central vein. Scale bars $=100 \mu \mathrm{m}$. mainly cholesterol had accumulated in the hepatocytes of rabbits fed HFD II. Expression of genes related to fat metabolism, such as peroxisome proliferator-activated receptor- $\gamma$ (PPAR $\gamma)$ and adipocyte lipid-binding protein (aP2), also known as fatty acid binding protein 4 , increased
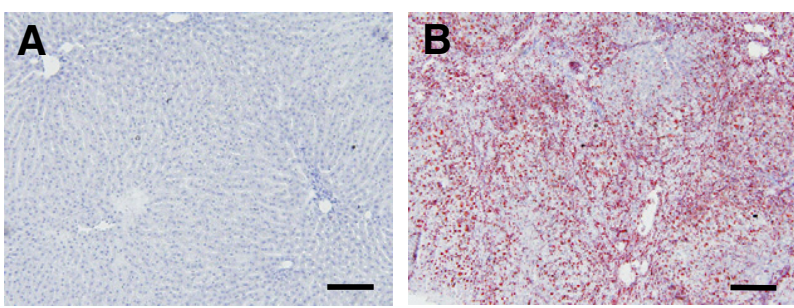

C
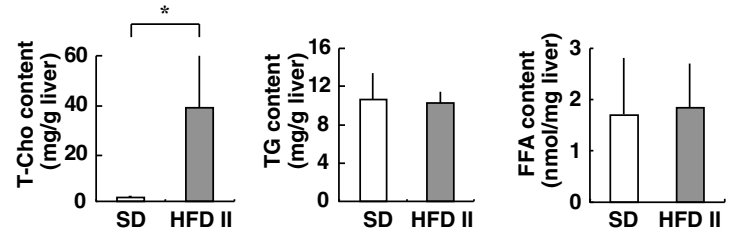

D
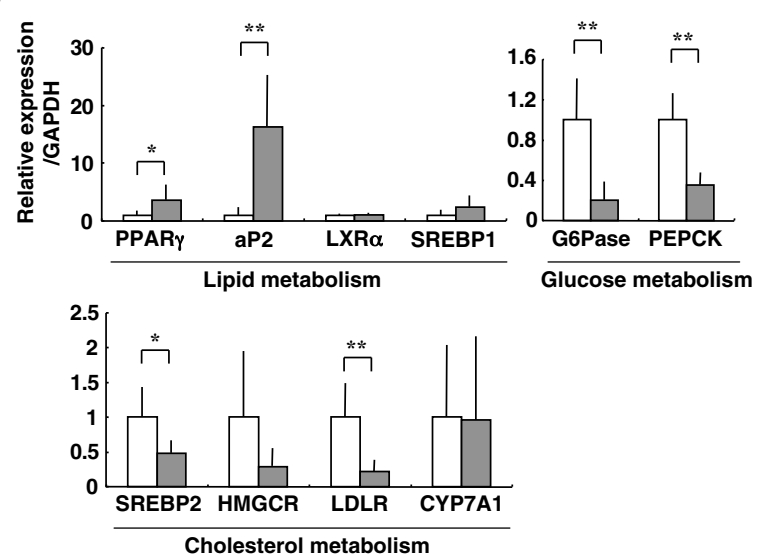

Figure 3. Metabolism of lipid, glucose, and cholesterol in the livers of HFD II-fed rabbits. Rabbits were fed SD (A) or HFD II (B) for nine months. A and B: Oil red O staining. Note hepatic lipid deposits in HFD II-fed rabbits. Scale bars $=100 \mu \mathrm{m}$. C: Hepatic T-Cho (left), TG (middle), and FFA (right) contents. Note that the hepatic T-Cho content increased significantly in HFD II-fed rabbits. D: Expression of lipid, glucose, and cholesterol metabolismrelated genes in the livers of SD-fed rabbits (white bars) and HFD II-fed rabbits (gray bars) analyzed by quantitative real-time PCR. " $P<0.05$; *** $P<0.01$. 
in rabbits fed HFD II, whereas glucose 6-phosphatase (G6Pase) and phosphoenolpyruvate carboxykinase (PEPCK), which are involved in glucose metabolism, were reduced in the livers of HFD II-fed rabbits (Figure 3D). Among cholesterol biosynthesis-related genes, expression of sterol regulatory element binding protein 2 (SREBP2) and low-density lipoprotein receptor (LDLR) was significantly reduced in the livers of HFD II-fed rabbits. Expression of 3-hydroxy-3-methylglutaryl-coenzyme A reductase (HMGCR) mRNA also tended to be reduced in livers, although not significantly. Cytochrome P450 7A1 (CYP7A1) mRNA levels remained unchanged.

\section{Hepatic Inflammation and Kupffer Cell Activation}

RAM-11, an antibody directed against rabbit macrophages, recognizes activated Kupffer cells, the resident liver macrophages. ${ }^{21}$ In contrast to the livers of SD-fed rabbits (Figure 4A), in the livers of HFD II-fed rabbits, the number of RAM-11-positive (RAM-11 ${ }^{+}$) cells increased drastically around the central vein area at sites where fatty degeneration of hepatocytes was evident (Figure 4B, see also Figure 2D). At a higher magnification (Figure $4 \mathrm{~B}$, inset), large RAM $-11^{+}$cells were localized in sinusoids, and they frequently contained vacuoles. In accordance with this observation, genes related to macrophage activation and cytokines, such as tumor necrosis factor $\alpha(\mathrm{TNF} \alpha)$; interleukin-1 $\beta$ (IL-1 $\beta)$, -10 (IL10), and -18 (IL18); Toll-like receptors 2 (TLR2) and 4 (TLR4); CD14 (a coreceptor with TLR 4); and MD2 (a complex with TLR4), were all induced in the livers of HFD II-fed rabbits (Figure 4C, Supplemental Table S2, see http://ajp.amjpathol.org).
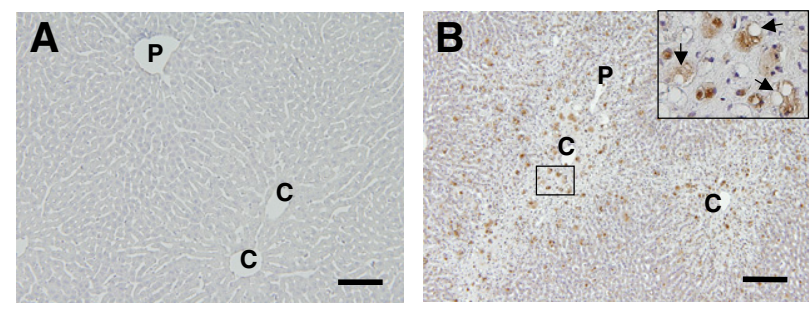

\section{C}

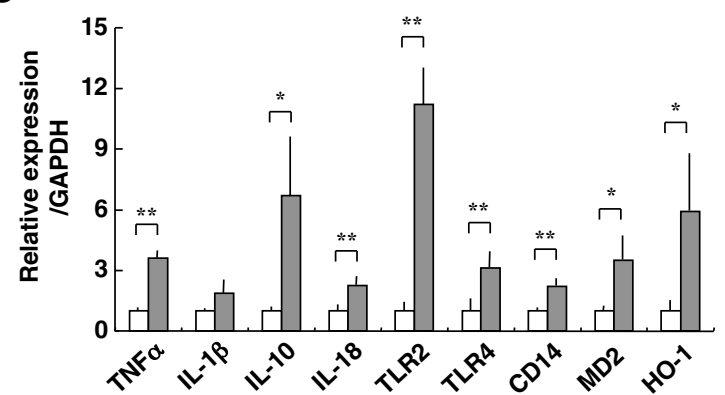

Figure 4. Activation of macrophages in the livers of HFD II-fed rabbits. Rabbits were fed SD (A) or HFD II (B) for nine months. A and B: Immunohistochemistry for the rabbit macrophage RAM-11 clone. Note RAM- $11^{+}$cells around the central vein area in HFD II-fed rabbits, whereas these cells are absent in SD-fed rabbits. Inset: enlarged view of the box. Arrows indicate RAM- $11^{+}$cells with large vacuoles. Scale bars $=100 \mu \mathrm{m}$. P, portal vein; C, central vein. C: Expression of inflammatory genes in the livers of SD-fed rabbits (white bars) and HFD II-fed rabbits (gray bars) analyzed by quantitative real-time PCR. ${ }^{*} P<0.05 ;{ }^{* *} P<0.01$.
A stress protein, heme oxygenase-1 (HO-1), was also increased significantly in the livers of HFD II-fed rabbits.

\section{Advanced Hepatic Fibrosis in Rabbits Fed High-Fat and-Cholesterol Diet II}

The livers of HFD II-fed rabbits showed evidence of advanced fibrosis. Sirius red staining showed a limited amount of red-colored collagen around portal and central veins in the control livers, whereas collagen deposition was marked in the livers of HFD II-fed rabbits (Figure 5, A and B). Fibrosis formed bridges between the central veins and central portal veins, indicating that the liver fibrosis was stage 3 (bridging fibrosis) or stage 4 (cirrhosis) according to the Brunt's staging score. The fibrotic septa were composed of cells positive for $\alpha \mathrm{SMA}$, a marker of activated stellate cells and myofibroblasts (Figure 5, C and D). Upregulated expression of $\alpha \mathrm{SMA}$ in HFD II-fed rabbits was confirmed by immunoblotting (Figure 5E). In addition, expression of genes associated with fibrosis, such as transforming growth factor $\beta 1$ (TGF $\beta 1$ ), collagens 1A1 (Col1A1) and 3A1 (Col3A1), matrix metalloproteinases-2 (MMP-2) and -9 (MMP-9), and tissue inhibitors of metalloproteinases-1 (TIMP-1) and -2 (TIMP-2), increased in the livers of HFD II-fed rabbits (Figure 5F, Supplemental Table S2, see http://ajp.amjpathol.org). Furthermore, genes for other matrix proteins such as
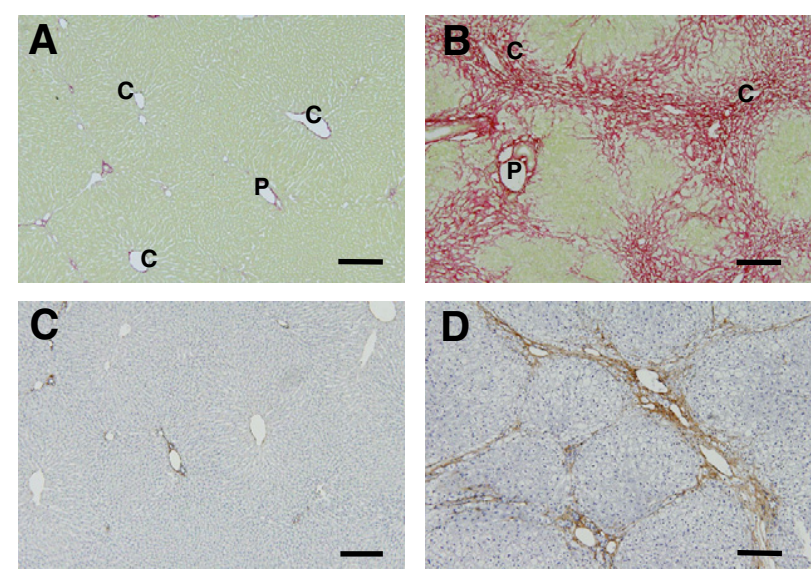

E

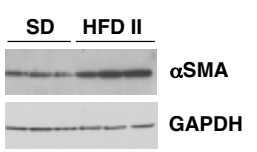

$\mathbf{F}$

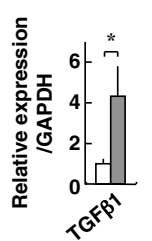

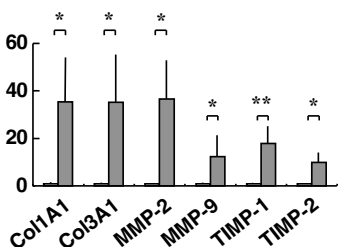

Figure 5. Progression of liver fibrosis in HFD II-fed rabbits. Rabbits were fed SD (A and $\mathbf{C})$ or HFD II (B and $\mathbf{D})$ for nine months. $\mathbf{A}$ and $\mathbf{B}$ : Sirius red staining. Note collagen deposits around the portal and central vein areas, as well as bridging fibrosis in HFD II-fed rabbits. P, portal vein; C, central vein. $\mathbf{C}$ and D: Immunohistochemistry for $\alpha \mathrm{SMA}$, a marker of activated stellate cells and myofibroblasts. Note that $\alpha \mathrm{SMA}^{+}$cells are mainly seen inside fibrotic septa in the livers of HFD II-fed rabbits. Scale bar $=100 \mu \mathrm{m}$. E: Immunoblotting for $\alpha$ SMA. Note that expression of $\alpha$ SMA was augmented in HFD II-fed rabbits. GAPDH was the internal control. F: Expression of fibrosis-related genes in the livers of SD-fed rabbits (white bars) and HFD II-fed rabbits (gray bars) analyzed by quantitative real-time PCR. ${ }^{*} P<0.05 ;{ }^{* *} P<0.01$. 


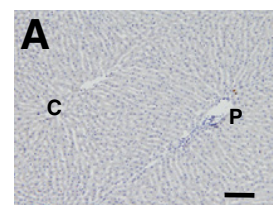

D
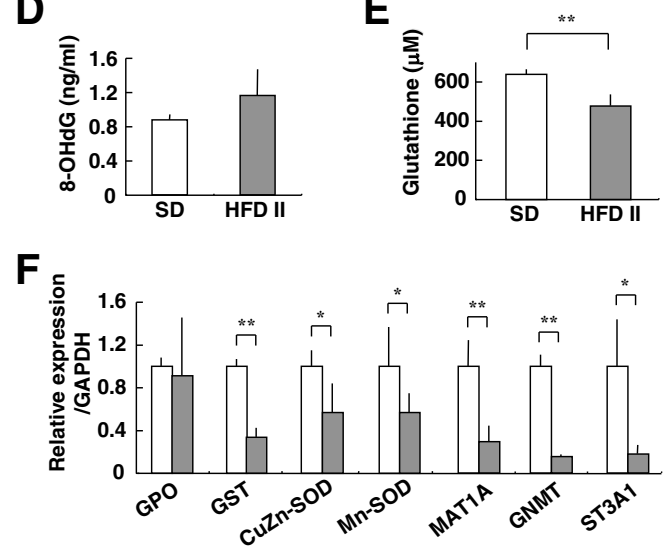

Figure 6. Detection of oxidative stress and levels of antioxidants in the liver. Rabbits were fed SD (A) or HFD II (B and C) for nine months. A-C: Staining of 4-HNE adducts in the liver. $\mathbf{C}$ : A magnified image of the region enclosed within the box in B. Note 4-HNE adducts in the hepatocytes (arrows) and sinusoidal cells (arrowheads) of HFD II-fed rabbits. Scale bars $=100 \mu \mathrm{m}$. D: Hepatic 8-hydroxy-2'-deoxyguanosine content. E: Glutathione content in the livers of SD- and HFD II-fed rabbits. F: Expression of mRNAs for antioxidantrelated genes and proteome analysis of liver proteins in SD-fed rabbits (white bars) and HFD II-fed rabbits (gray bars). ${ }^{*} P<0.05 ;{ }^{* *} P<0.01$.

collagen 8A1, MMP-12, TIMP-3, lumican, decorin, and biglycan showed increased expression in the livers of HFD II-fed rabbits (Supplemental Table S2, see http://ajp.amjpathol.org).

\section{Oxidative Stress and Antioxidant Imbalance in Rabbits Fed High-Fat and-Cholesterol Diet II}

Immunohistochemical analysis showed that 4-HNE adduct formation was rare in SD-fed rabbits but was prom- inent in HFD II-fed rabbits. The 4-HNE adducts were present in the cytoplasm of sinusoidal cells and hepatocytes around the central vein areas (Figure 6, A-C), indicating increased lipid peroxidation in HFD II-fed rabbit livers as in human NASH. ${ }^{22}$ Moreover, the 8-hydroxy2 '-deoxyguanosine level increased, although not significantly, in both liver tissue and urine of HFD II-fed rabbits (Figure 6D, Table 3). As a measure of the presence of oxidative stress, the hepatic level of glutathione was determined in SD- and HFD II-fed rabbits; HFD II significantly reduced its levels (Figure 6E). In addition, the expression of genes for glutathione S-transferase (GST) and other antioxidant molecules, such as Cu,Zn-superoxide dismutase (Cu,Zn-SOD) and Mn-superoxide dismutase (Mn-SOD), decreased significantly in HFD II-fed rabbits (Figure 6F, Supplemental Table S2, see http:// ajp.amjpathol.org). We measured the serum or urine levels of molecules that reflect oxidative stress. The levels of copper, $\delta$-tocopherol, and coenzyme Q10 (ubiquinol and ubiquinone) increased significantly in HFD II-fed rabbits, whereas folic acid and vitamin A decreased significantly (Table 3). Comparison of hepatic protein distribution profiles on two-dimensional SDS-PAGE gels between SDand HFD II-fed rabbits revealed proteins that were both up- and down-regulated by HFD II (Figure 7). GST was identified as a markedly down-regulated protein in HFD Il-fed rabbits. Other down-regulated proteins in HFD II-fed rabbits by proteome analysis were glycine N-methyltransferase (GNMT), methionine adenosyltransferase 1 (MAT1), and sulfotransferase 3A1 (ST3A1). These genes also showed significantly lower expression in the livers of HFD II-fed rabbits (Figure 6F).

\section{Effect of Ezetimibe on the Rabbit NASH Model}

To further evaluate the rabbit NASH model, we investigated the effect of a known compound that suppresses the occurrence of $\mathrm{NASH}$ through a known mechanism.

Table 3. Profile of Oxidative Stress Markers and Antioxidants in Serum and Urine

\begin{tabular}{|c|c|c|c|c|}
\hline & SD & HFD ॥ & Source & $P$ value \\
\hline \multicolumn{5}{|l|}{ Oxidative stress } \\
\hline 8-OHdG (ng/mg creatinine) & $43.0 \pm 37.7$ & $101.1 \pm 34.6$ & Urine & NS \\
\hline Isoplastane (ng/mg creatinine) & $4.0 \pm 5.3$ & $18.2 \pm 24.8$ & Urine & NS \\
\hline Lipid peroxide $(\mathrm{nmol} / \mathrm{ml})$ & $2.5 \pm 1.0$ & $3.7 \pm 0.4$ & Serum & NS \\
\hline \multicolumn{5}{|l|}{ Antioxidants } \\
\hline Iron $(\mu \mathrm{g} / \mathrm{dl})$ & $142.8 \pm 65.7$ & $115.9 \pm 24.5$ & Serum & NS \\
\hline Copper $(\mu \mathrm{g} / \mathrm{dl})$ & $46.8 \pm 2.9$ & $156.3 \pm 5.9$ & Serum & $P<0.01$ \\
\hline STAS $(\mu \mathrm{M})$ & $969.0 \pm 39.8$ & $958.7 \pm 143.5$ & Serum & NS \\
\hline \multicolumn{5}{|l|}{ Aqueous antioxidants } \\
\hline Vitamin $C(\mu \mathrm{g} / \mathrm{ml})$ & $3.9 \pm 1.3$ & $6.3 \pm 2.9$ & Serum & NS \\
\hline Folic acid (ng/ml) & $55.8 \pm 11.6$ & $21.3 \pm 12.5$ & Serum & $P<0.05$ \\
\hline \multicolumn{5}{|l|}{ Liposoluble antioxidants } \\
\hline Vitamin A $(\mu \mathrm{g} / \mathrm{dl})$ & $92.3 \pm 5.1$ & $37.6 \pm 6.7$ & Serum & $P<0.01$ \\
\hline \multicolumn{5}{|l|}{ Vitamin $E$ fraction } \\
\hline$\alpha$-Tocopherol ( $\mu \mathrm{g} / \mathrm{dl})$ & $95.0 \pm 81.4$ & $3499.7 \pm 5040.3$ & Serum & NS \\
\hline$\delta$-Tocopherol $(\mu \mathrm{g} / \mathrm{dl})$ & $<2.5$ & $31.2 \pm 10.4$ & Serum & $P<0.05$ \\
\hline$\gamma$-Tocopherol ( $\mu \mathrm{g} / \mathrm{dl})$ & $6.5 \pm 2.7$ & $706.9 \pm 944.2$ & Serum & NS \\
\hline \multicolumn{5}{|l|}{ Coenzyme Q10 } \\
\hline Ubiquinol (nmol/L) & $58.0 \pm 10.8$ & $489.3 \pm 151.3$ & Serum & $P<0.05$ \\
\hline Ubiquinone (nmol/L) & N.D. & $36.7 \pm 23.7$ & Serum & $P<0.01$ \\
\hline
\end{tabular}

NS, not significant. 


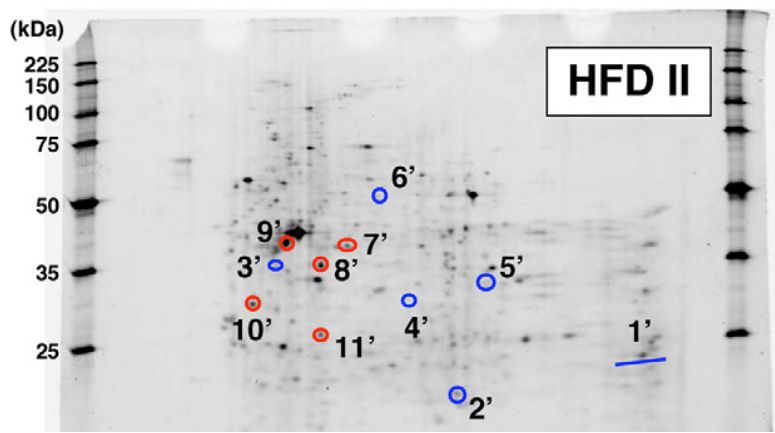

Figure 7. Two-dimensional SDS-PAGE analysis of hepatic proteins. Rabbits were fed SD or HFD II for nine months. Proteins were extracted from the livers of SD- and HFD II-fed rabbits and were separated by two-dimensional SDS-PAGE. After the gels were stained with SYPRO Ruby, the protein spots were cut out, digested, and analyzed by quadrupole time-of-flight. Then, the proteins were identified from the obtained amino acid sequences using protein BLAST or FASTA databases. 1 and $1^{\prime}$, glutathione transferase; 2 and $2^{\prime}$, glutathione $S$-transferase Yc $\left(\alpha\right.$ II); 3 and $3^{\prime}$, MAT1; 4 and $4^{\prime}$, ST3A1; 5 and $5^{\prime}$, GNMT; 6 and $6^{\prime}$, aldehyde dehydrogenase, mitochondrial (ALDH class 2); 7 and $7^{\prime}$, keratin, type II or cytoskeletal 2 epidermal; 8 and $8^{\prime}, \alpha$-tubulin, actin, $\beta$-like 2 , or similar to actin, cytoplasmic $1 ; 9$ and $9^{\prime}$, actin, $\beta$-like $2 ; 10$ and $10^{\prime}$, keratin 10 or CYP2B3; 11 and $11^{\prime}$, similar to actin, cytoplasmic 1 . Blue circles, proteins down-regulated in HFD II-fed rabbits; red circles, proteins up-regulated in HFD II-fed rabbits

Because a marked increase in serum and hepatic T-Cho levels was evident in our HFD-fed rabbits, we tested ezetimibe, a relatively new compound that inhibits NPC1L1 in hepatocytes and the intestine. Rabbits were fed HFD I (the original diet) with or without ezetimibe (0.6 $\mathrm{mg} / \mathrm{kg} /$ day) for 2 months. Both control and experimental rabbits showed normal increases in body weight (data not shown). Levels of AST, ALT, and TG remained within the normal range in rabbits fed HFD I with or without ezetimibe (AST, $38.0 \pm 18.4$ versus $20.8 \pm 7.4 \mathrm{IU} / \mathrm{L} ;$ ALT, $11.0 \pm 1.0$ versus $7.8 \pm 3.0 \mathrm{lU} / \mathrm{L}$; and $\mathrm{TG}, 31.0 \pm 9.5$ versus $27.4 \pm 16.8 \mathrm{mg} / \mathrm{dl}$ ). Serum T-Cho was significantly lower in HFD l-fed rabbits treated with ezetimibe than in untreated rabbits during the course of ezetimibe-treatment for up to 8 weeks (Figure 8A). A histological examination showed that ezetimibe suppressed fat deposition (Figure 8, B-F) and reduced the hepatic content of total T-Cho and TG (Figure 8G). Furthermore, liver fibrosis, mildly induced in this 2-month HFD I model, was suppressed by the ezetimibe treatment (Figure 9, A-D). Moreover, ezetimibe significantly decreased the expression of genes associated with liver fibrosis, such as TGF $\beta 1$, MMP-9, and TIMP-1 and -2. The drug also suppressed expression of Col1A1 and MMP-2, although the difference was not significant (Figure 9E).
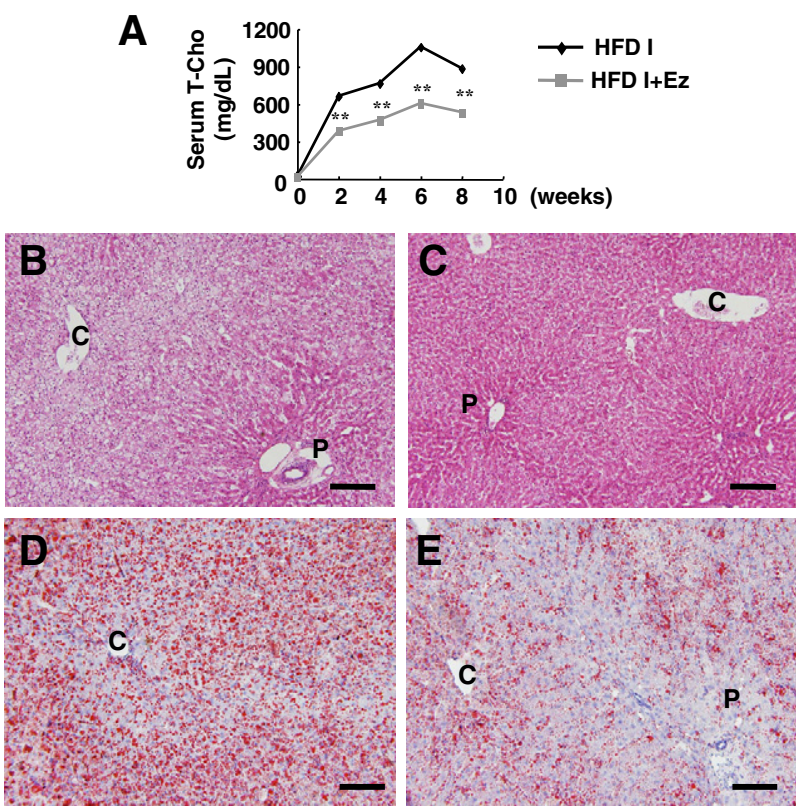

$\mathbf{F}$

G
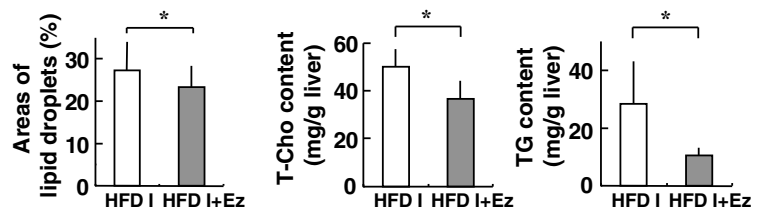

Figure 8. Effect of ezetimibe (Ez) on hepatic steatosis in HFD I-fed rabbits. Rabbits were fed HFD I (the original diet) with or without ezetimibe (0.6 $\mathrm{mg} / \mathrm{kg} /$ day) (HFD I or HFD I + Ez) for two months. Histological sections were prepared from HFD I-fed (B and $\mathbf{D})$ and HFD I + Ez-fed rabbits $(\mathbf{C}$ and E). A: Changes in serum T-Cho levels. B and C: H\&E staining. D and E: Oil red O staining. Scale bars $=100 \mu \mathrm{m}$. F: Quantification of the lipid droplet area in the liver. Oil red O-stained areas were measured in the livers of HFD I- and HFD I + Ez-fed rabbits. The stained area was significantly smaller in HFD I + Ez-fed rabbits. G: Hepatic total cholesterol and triglyceride contents. $\mathrm{P}$, portal vein; C, central vein. HFD I, $n=5$. HFD I + Ez, $n=5 .{ }^{*} P<0.05$; **: $P<0.01$

\section{Discussion}

There are several important differences in characteristics of NASH between this rabbit model and humans. Hepatic levels of cholesterol, but not of TG and FFA, exhibited a marked increase in HFD II-fed rabbits compared with those in SD-fed rabbits, and the PPAR $\gamma$ and aP2 mRNA levels were induced in the HFD II model in a manner similar to that observed in human NASH (Figure 3, C and D). ${ }^{26,27}$ NAFLD shows various patterns of lipid deposition in the liver, ${ }^{28}$ which may be influenced by the diet composition. In this context, increased PPAR $y$ and aP2 may contribute to a decrease in cholesterol level in hepatocytes of this rabbit model induced by high-cholesterol diets. Mitochondrial free cholesterol, but not TG and FFA, sensitizes hepatocytes to TNF $\alpha$ - and Fas-induced apoptosis through mitochondrial glutathione exhaustion. ${ }^{29}$ We also observed a marked reduction in glutathione and glutathione-metabolic enzymes in the HFD II-fed rabbit livers (Figure 6, E and F). In this context, it is likely that cholesterol overload, together with a dysregulated antioxidative system in hepatocytes, may trigger liver injury. ${ }^{30,31}$ Furthermore, this rabbit model showed increased levels 

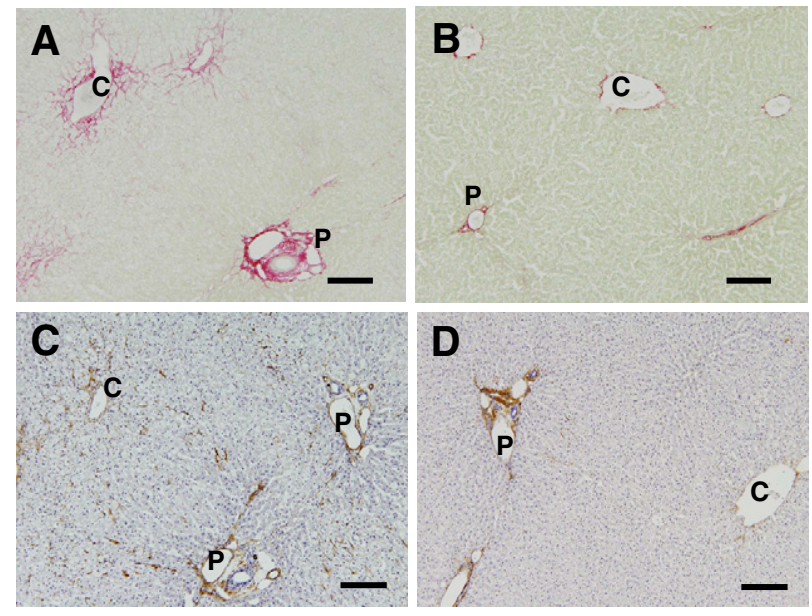

E

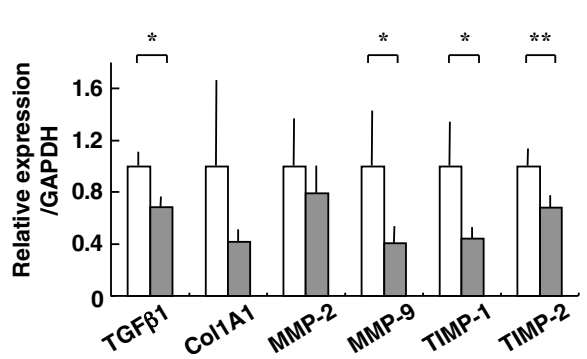

Figure 9. Effect of ezetimibe (Ez) on liver fibrosis in HFD I-fed rabbits. Rabbits were fed HFD I (the original diet) with or without ezetimibe ( 0.6 $\mathrm{mg} / \mathrm{kg} /$ day) (HFD I or HFD I + Ez) for two months as mentioned in Figure 8. Histological sections were prepared from HFD I-fed (A and $\mathbf{C}$ ) and HFD I + Ez-fed rabbits (B and D). A and B: Liver sections were stained with Sirius red. Collagen depositions were reduced by ezetimibe administration. $\mathbf{C}$ and D: Liver sections were immunostained for $\alpha$ SMA. Note that the $\alpha \mathrm{SMA}^{+}$cells were reduced by ezetimibe administration. Scale bars $=100 \mu \mathrm{m}$. E: Expression of fibrosis-related genes in the liver of HFD I-fed rabbits (white bars) and HFD I + Ez-fed rabbits (gray bars). P, portal vein; C, central vein. HFD I, $n=$ 5. HFD I + Ez, $n=5$. Ez, ezetimibe. ${ }^{*} P<0.05 ;{ }^{* *} P<0.01$.

of serum bile acids (Table 2), which are presumably induced by cholesterol overload and down-regulation of the bile acid export-related genes, such as the bile salt export pump and multidrug resistance-associated protein 2 (data not shown).

Although it has been reported that FFA and leptin increase and adiponectin decreases in the serum of NASH patients, ${ }^{32}$ serum and hepatic levels of FFA did not change in this rabbit model, possibly owing to the lack of obesity. A recent study reported the reduction of serum adiponectin in a rabbit model fed 10\% lard and $2 \%$ cholesterol-containing HFD for 8 and 12 weeks. ${ }^{33}$ Unfortunately, we were unable to determine the adiponectin and leptin levels in our rabbit model for unknown reasons (data not shown).

We also observed no increase in fasting glucose, fasting insulin, or HOMA-IR in this rabbit model. However, as stated above, this rabbit model showed no obesity and failed to induce high FFA levels in the liver and serum, which may be reasons for its failure to induce type II diabetes and insulin resistance. Furthermore, as shown in Figure 3D, G6Pase and PEPCK mRNA expression levels were markedly suppressed in the HFD II model, similar to a report on cirrhotic NASH patients. ${ }^{34}$ Cholesterol overload and the resulting hepatocyte dysfunction in cirrhosis are assumed to be the reasons for this down-regulation, indicating the actual impairment of glucose metabolism in the HFD II liver.

The serum ALT level has long been used as a surrogate marker for liver injury. However, ALT values do not correlate well with the severity of liver injury in human NAFLD. ${ }^{35,36}$ Similar to that in patients with NAFLD but that inunlike viral or drug-induced hepatitis, the ALT level in this rabbit model remained unchanged, but the mechanism remains unknown and should be clarified in future research.

Gut-derived lipopolysaccharide activates Kupffer cells by activating lipopolysaccharide receptors, ${ }^{37}$ leading to increased production of inflammatory cytokines such as TNF $\alpha$, IL-8, and IL-18. ${ }^{38,39}$ The development of steatohepatitis in a NASH model, induced by a methionine- and choline-deficient diet, was partly inhibited in TLR4 mutant mice, ${ }^{40,41}$ suggesting a role for TLR4-dependent signaling in the occurrence of this type of liver damage. In addition, the lipoprotein component of endotoxin from Gram-negative and -positive bacteria activates TLR2 and/or TLR4, which leads to common downstream activation of TRAF6 via the adapter molecule MyD88. ${ }^{42}$ This cascade of events culminates in nuclear factor- $\kappa$ B activation, leading to the induction of TNF $\alpha$ and other proinflammatory cytokines. ${ }^{42}$ Although TNF $\alpha$ has been identified as a central mediator contributing to insulin resistance and liver damage in $\mathrm{NASH}$, little is known about the role of TLR2 or TLR4 in the induction of TNF $\alpha$. In the present study, we observed an increase in the expression of TLR4/CD14/MD2 and TLR2 and cytokine induction in HFD II-fed rabbits. Persistent hepatic inflammation also triggers the activation of stellate cells and excess collagen production, resulting in the development of liver fibrosis. ${ }^{43,44}$ Stellate cells are activated by LPS through TLR4/CD14/MD2 signaling. ${ }^{45,46}$ Thus, the role of LPS in triggering steatohepatitis in this HFD II model deserves to be studied further in relation to hepatic fibrogenesis.

In the present study, we showed a reduction in hepatic glutathione content and decreased GST and SOD mRNA expression. Serum levels of antioxidants such as vitamin E, copper, and coenzyme Q10 increased significantly, but the levels of vitamin A and folic acid decreased significantly. As a result, there was an imbalance between oxidative stress and antioxidant protection systems in the present steatohepatitis model, as in human NASH patients. ${ }^{47-52}$ The molecular mechanisms leading to the dysregulation of small antioxidant molecules are currently unknown. Most vitamin A in the body (approximately $70 \%$ ) is usually stored in quiescent hepatic stellate cells, ${ }^{53}$ but vitamin A storage is impeded when stellate cells are activated, under which activation they express $\alpha$ SMA and produce extracellular matrix materials including type I collagen. ${ }^{43,44}$ Thus, the reduction of serum vitamin A levels may reflect activation of stellate cells and the progression of fibrosis in our rabbits with HFD II-induced NASH. Folic acid is reportedly involved in the maintenance of normal concentrations of homocysteine, methionine, and S-adenosylmethionine. ${ }^{54}$ Folic acid deficiency and abnormal hepatic methionine metabolism 
are characteristics of alcoholic liver disease. ${ }^{54}$ Thus, the reduction in serum folic acid observed in our rabbit NASH model might be a common feature of both alcoholic and nonalcoholic liver disease. Furthermore, the proteome analysis identified a reduction in GNMT and MAT1, which are associated with liver steatosis and fibrosis, in HFD Il-fed rabbits. ${ }^{55-57}$ Martínez-Chantar et al ${ }^{55}$ showed that GNMT-knockout mice exhibited an elevation in serum aminotransferase, methionine, and S-adenosylmethionine and developed hepatic steatosis, fibrosis, and hepatocellular carcinoma. MAT1A-knockout mice were also reported to show liver steatosis. ${ }^{57}$ These enzymes play an important role in the synthesis and degradation of S-adenosylmethionine. ${ }^{56}$ Thus, an imbalance in S-adenosylmethionine and methionine metabolism may play a role in the development of steatohepatitis in our model. ${ }^{58}$

Phagocytic NADPH oxidases, such as gp91-phox, p40-phox, p67-phox, and p22-phox, increased in the present rabbit model (Supplemental Table S2, see $h t t p: / /$ ajp.amjpathol.org); however, the role of NADPH oxidase, a key molecule in the development of atherosclerosis, ${ }^{59}$ in NASH is poorly understood. In alcoholic liver injury, NADPH oxidase is important for reactive oxygen species production in Kupffer cells and in hepatic stellate cells that initiate and promote liver injury. ${ }^{60,61}$ We previously reported that the phagocytic activity of Kupffer cells promotes oxidative stress, inflammation, and fibrosis in steatohepatitis. ${ }^{7}$ In this context, NADPH oxidase could play a prominent role in the pathogenesis of human NASH.

In the present study, we created a rabbit model of steatohepatitis, in which advanced fibrosis (close to cirrhosis) was produced by feeding a HFD. Hypercholesterolemia is a risk factor for liver injury as well as for atherosclerosis; ${ }^{2-5}$ therefore, lowering the serum T-Cho level by dieting or by medications that reduce the synthesis and absorption of cholesterol could be a promising therapy for NAFLD including NASH. In this context, statins, which are HMG-CoA reductase inhibitors, have been reported to improve $\mathrm{NASH}^{62,63}$ Rallidis et al ${ }^{62}$ showed that pravastatin treatment lowered serum ALT and improved histological steatosis in $5 \mathrm{NASH}$ patients. Hyogo et al ${ }^{63}$ treated patients with atorvastatin and found that 23 patients $(74.2 \%)$ exhibited normalized transaminases and histological improvement of liver steatosis and the NAFLD activity score, and these changes were accompanied by a significant increase in serum adiponectin and a significant decrease in serum TNF $\alpha$. In the present study, we studied the effect of ezetimibe, which inhibits NPC1L1 and therefore blocks intestinal absorption of cholesterol from the diet or that excreted in the bile. ${ }^{11-15}$ The effect of ezetimibe on NASH has already been reported in rat models. Assy et a ${ }^{19}$ studied methionine and choline deficiency-induced steatohepatitis in rats, in which ezetimibe administration alone or together with rosiglitazone, metformin, and valsartan reduced the hepatic levels of TG, T-Cho, and malondialdehyde and also significantly attenuated histological steatosis. In Zucker obese fatty rats, Deushi et $\mathrm{al}^{18}$ reported that ezetimibe administration reduced the serum and hepatic levels of T-Cho and TG, the number of Oil red O-positive hepatocytes, Sirius red-stained collagen deposition, and $\alpha \mathrm{SMA}$ expression. Supporting these observations, we demonstrated the usefulness of ezetimibe treatment in a rabbit NASH model. Because human lipid metabolism is similar to that of rabbits but is different from that of mice and rats, our results strengthen the potential of ezetimibe for controlling fat deposition and fibrosis in human NASH. Interestingly, ezetimibe not only improved HFD I-induced liver steatosis but also reduced fibrosis and the number of $\alpha \mathrm{SMA}^{+}$cells. In chronic liver disease, TGF $\beta 1$ plays an important role in the progression of liver fibrosis and stellate cell activation. ${ }^{43,44}$ TGF $\beta 1$ produced by Kupffer cells and stellate cells activates stellate cells in a paracrine as well as an autocrine manner and stimulates type I collagen production. In our rabbit model, ezetimibe reduced TGF $\beta 1$ and type I collagen expression in the liver. Unlike mice, humans and rabbits show abundant NPC1L1 expression in the liver. ${ }^{15}$ Further studies are required to clarify the effect of ezetimibe prophylactically after the HFD-fed rabbits have already developed steatohepatitis and to examine whether ezetimibe directly affects cholesterol metabolism in hepatocytes, thereby participating in the local prevention of fibrosis caused by abnormal cholesterol metabolism. ${ }^{14}$

In conclusion, rabbits fed HFD II for 9 months developed steatohepatitis with advanced fibrosis accompanied by the augmented expression of relevant genes. We demonstrated the presence of an imbalance between oxidative stress and antioxidant levels in HFD II-fed rabbits. Ezetimibe therapy was promising for alleviating the pathological changes in this model, suggesting the potential usefulness of this compound for human liver diseases caused by cholesterol overload.

\section{Acknowledgments}

We thank Dr. Ryoko Shiga, Dr. Yong-ping Mu, Ms. Mami Mori, Ms. Michiko Ohashi, and Ms. Asuka Yoshida for their technical support.

\section{References}

1. Ford ES, Giles WH, Dietz WH: Prevalence of the metabolic syndrome among US adults: findings from the Third National Health and Nutrition Examination Survey. JAMA 2002, 287:356-359

2. Angulo P: Nonalcoholic fatty liver disease. N Engl J Med 2002 346:1221-1231

3. Ludwig J, Viggiano TR, McGill DB, Oh BJ: Nonalcoholic steatohepatitis: Mayo Clinic experiences with a hitherto unnamed disease. Mayo Clin Proc 1980, 55:434-438

4. Matteoni CA, Younossi ZM, Gramlich T, Boparai N, Liu YC, McCullough AJ: Nonalcoholic fatty liver disease: a spectrum of clinical and pathological severity. Gastroenterology 1999, 116:1413-1419

5. Brunt EM, Janney CG, Di Bisceglie AM, Neuschwander-Tetri BA, Bacon BR: Nonalcoholic steatohepatitis: a proposal for grading and staging the histological lesions. Am J Gastroenterol 1999, 94:2467-2474

6. Neuschwander-Tetri BA, Caldwell SH: Nonalcoholic steatohepatitis: summary of an AASLD Single Topic Conference. Hepatology 2003, 37:1202-1219

7. Otogawa K, Kinoshita K, Fujii H, Sakabe M, Shiga R, Nakatani K, Ikeda K, Nakajima Y, Ikura Y, Ueda M, Arakawa T, Hato F, Kawada N Erythrophagocytosis by liver macrophages (Kupffer cells) promotes oxidative stress, inflammation, and fibrosis in a rabbit model of 
steatohepatitis: implications for the pathogenesis of human nonalcoholic steatohepatitis. Am J Pathol 2007, 170:967-980

8. Buja LM, Kita T, Goldstein JL, Watanabe Y, Brown MS: Cellular pathology of progressive atherosclerosis in the WHHL rabbit. An animal model of familial hypercholesterolemia. Arteriosclerosis 1983, 3:87-101

9. Okita M, Hayashi M, Sasagawa T, Takagi K, Suzuki K, Kinoyama S, Ito T, Yamada G: Effect of a moderately energy-restricted diet on obese patients with fatty liver. Nutrition 2001, 17:542-547

10. Huang MA, Greenson JK, Chao C, Anderson L, Peterman D, Jacobson J, Emick D, Lok AS, Conjeevaram HS: One-year intense nutritional counseling results in histological improvement in patients with non-alcoholic steatohepatitis: a pilot study. Am J Gastroenterol 2005, 100:1072-1081

11. Altmann SW, Davis HR Jr, Zhu LJ, Yao X, Hoos LM, Tetzloff G, Iyer SP Maguire M, Golovko A, Zeng M, Wang L, Murgolo N, Graziano MP: Niemann-Pick C1 like 1 protein is critical for intestinal cholesterol absorption. Science 2004, 303:1201-1204

12. Davis HR Jr, Zhu LJ, Hoos LM, Tetzloff G, Maguire M, Liu J, Yao X, lyer SP, Lam MH, Lund EG, Detmers PA, Graziano MP, Altmann SW: Niemann-Pick C1 like 1 (NPC1L1) is the intestinal phytosterol and cholesterol transporter and a key modulator of whole-body cholesterol homeostasis. J Biol Chem 2004, 279:33586-33592

13. Temel RE, Tang W, Ma Y, Rudel LL, Willingham MC, loannou YA, Davies JP, Nilsson LM, Yu L: Hepatic Niemann-Pick C1-like 1 regulates biliary cholesterol concentration and is a target of ezetimibe. J Clin Invest 2007, 117:1968-1978

14. Ge L, Wang J, Qi W, Miao HH, Cao J, Qu YX, Li BL, Song BL: The cholesterol absorption inhibitor ezetimibe acts by blocking the sterolinduced internalization of NPC1L1. Cell Metab 2008, 7:508-519

15. Hawes BE, O'Neill KA, Yao X, Crona JH, Davis HR Jr, Graziano MP, Altmann SW: In vivo responsiveness to ezetimibe correlates with Niemann-Pick C1 like-1 (NPC1L1) binding affinity: comparison of multiple species NPC1L1 orthologs. Mol Pharmacol 2007, 71:19-29

16. Knopp RH, Dujovne CA, Le Beaut A, Lipka LJ, Suresh R, Veltri EP: Evaluation of the efficacy, safety, and tolerability of ezetimibe in primary hypercholesterolaemia: a pooled analysis from two controlled phase III clinical studies. Int J Clin Pract 2003, 57:363-368

17. Gómez-Garre D, Munoz-Pacheco P, Gonzalez-Rubio ML, Aragoncillo $P$, Granados R, Fernandez-Cruz A: Ezetimibe reduces plaque inflammation in a rabbit model of atherosclerosis and inhibits monocyte migration in addition to its lipid-lowering effect. Br J Pharmacol 2009, 156:1218-1227

18. Deushi M, Nomura M, Kawakami A, Haraguchi M, Ito M, Okazaki M, Ishii $\mathrm{H}$, Yoshida M: Ezetimibe improves liver steatosis and insulin resistance in obese rat model of metabolic syndrome. FEBS Lett 2007, 581:5664-5670

19. Assy N, Grozovski M, Bersudsky I, Szvalb S, Hussein O: Effect of insulin-sensitizing agents in combination with ezetimibe, and valsar$\tan$ in rats with non-alcoholic fatty liver disease. World J Gastroenterol 2006, 12:4369-4376

20. Yamagishi S, Nakamura K, Matsui T, Sato T, Takeuchi M: Inhibition of intestinal cholesterol absorption by ezetimibe is a novel therapeutic target for fatty liver. Med Hypotheses 2006, 66:844-846

21. Buyssens N, Kockx MM, Herman AG, Lazou JM, Van den Berg K, Wisse E, Geerts A: Centrolobular liver fibrosis in the hypercholesterolemic rabbit. Hepatology 1996, 24:939-946

22. Seki S, Kitada T, Yamada T, Sakaguchi H, Nakatani K, Wakasa K: In situ detection of lipid peroxidation and oxidative DNA damage in non-alcoholic fatty liver diseases. J Hepatol 2002, 37:56-62

23. Otogawa K, Ogawa T, Shiga R, Nakatani K, Ikeda K, Nakajima $Y$, Kawada N: Attenuation of acute and chronic liver injury in rats by iron-deficient diet. Am J Physiol Regul Integr Comp Physiol 2008, 294:R311-R320

24. Kawada N, Kristensen DB, Asahina K, Nakatani K, Minamiyama Y, Seki S, Yoshizato K: Characterization of a stellate cell activationassociated protein (STAP) with peroxidase activity found in rat hepatic stellate cells. J Biol Chem 2001, 276:25318-25323

25. Kristensen DB, Kawada N, Imamura K, Miyamoto Y, Tateno C, Seki S, Kuroki T, Yoshizato K: Proteome analysis of rat hepatic stellate cells. Hepatology 2000, 32:268-277

26. Greco D, Kotronen A, Westerbacka J, Puig O, Arkkila P, Kiviluoto T, Laitinen S, Kolak M, Fisher RM, Hamsten A, Auvinen P, Yki-Jarvinen $\mathrm{H}$ : Gene expression in human NAFLD. Am J Physiol Gastrointest Liver Physiol 2008, 294:G1281-G1287
27. Nakamuta M, Kohjima M, Morizono S, Kotoh K, Yoshimoto T, Miyagi I, Enjoji M: Evaluation of fatty acid metabolism-related gene expression in nonalcoholic fatty liver disease. Int J Mol Med 2005, 16:631-635

28. Puri $P$, Baillie RA, Wiest MM, Mirshahi F, Choudhury J, Cheung O, Sargeant C, Contos MJ, Sanyal AJ: A lipidomic analysis of nonalcoholic fatty liver disease. Hepatology 2007, 46:1081-1090

29. Marí M, Caballero F, Colell A, Morales A, Caballeria J, Fernandez A, Enrich C, Fernandez-Checa JC, Garcia-Ruiz C: Mitochondrial free cholesterol loading sensitizes to TNF- and Fas-mediated steatohepatitis. Cell Metab 2006, 4:185-198

30. Begriche K, Igoudjil A, Pessayre D, Fromenty B: Mitochondrial dysfunction in NASH: causes, consequences and possible means to prevent it. Mitochondrion 2006, 6:1-28

31. Parola M, Robino G: Oxidative stress-related molecules and liver fibrosis. J Hepatol 2001, 35:297-306

32. Musso G, Gambino R, Durazzo M, Biroli G, Carello M, Faga E, Pacini G, De Michieli F, Rabbione L, Premoli A, Cassader M, Pagano G: Adipokines in NASH: postprandial lipid metabolism as a link between adiponectin and liver disease. Hepatology 2005, 42:1175-1183

33. Fu JF, Fang YL, Liang L, Wang CL, Hong F, Dong GP: A rabbit model of pediatric nonalcoholic steatohepatitis: the role of adiponectin. World J Gastroenterol 2009, 15:912-918

34. Sreekumar R, Rosado B, Rasmussen D, Charlton M: Hepatic gene expression in histologically progressive nonalcoholic steatohepatitis. Hepatology 2003, 38:244-251

35. Mofrad P, Contos MJ, Haque M, Sargeant C, Fisher RA, Luketic VA, Sterling RK, Shiffman ML, Stravitz RT, Sanyal AJ: Clinical and histologic spectrum of nonalcoholic fatty liver disease associated with normal ALT values. Hepatology 2003, 37:1286-1292

36. Wong VW, Wong GL, Tsang SW, Hui AY, Chan AW, Choi PC, Chim AM, Chu S, Chan FK, Sung JJ, Chan HL: Metabolic and histological features of non-alcoholic fatty liver disease patients with different serum alanine aminotransferase levels. Aliment Pharmacol Ther 2009, 29:387-396

37. Enomoto N, Yamashina S, Kono H, Schemmer P, Rivera CA, Enomoto A, Nishiura T, Nishimura T, Brenner DA, Thurman RG: Development of a new, simple rat model of early alcohol-induced liver injury based on sensitization of Kupffer cells. Hepatology 1999, 29:1680-1689

38. Tomita K, Tamiya G, Ando S, Ohsumi K, Chiyo T, Mizutani A, Kitamura N, Toda K, Kaneko T, Horie Y, Han JY, Kato S, Shimoda M, Oike Y, Tomizawa M, Makino S, Ohkura T, Saito H, Kumagai N, Nagata H, Ishii $\mathrm{H}$, Hibi T: Tumour necrosis factor $\alpha$ signalling through activation of Kupffer cells plays an essential role in liver fibrosis of non-alcoholic steatohepatitis in mice. Gut 2006, 55:415-424

39. Wang HN, Wang YR, Liu GQ, Liu Z, Wu PX, Wei XL, Hong TP: Inhibition of hepatic interleukin-18 production by rosiglitazone in a rat model of nonalcoholic fatty liver disease. World J Gastroenterol 2008, 14:7240-7246

40. Szabo G, Velayudham A, Romics L Jr, Mandrekar P: Modulation of non-alcoholic steatohepatitis by pattern recognition receptors in mice: the role of Toll-like receptors 2 and 4. Alcohol Clin Exp Res 2005, 29:140S-145S

41. Rivera CA, Adegboyega P, van Rooijen N, Tagalicud A, Allman M, Wallace M: Toll-like receptor-4 signaling and Kupffer cells play pivotal roles in the pathogenesis of non-alcoholic steatohepatitis. J Hepatol 2007, 47:571-579

42. Akira S, Takeda K: Toll-like receptor signalling. Nat Rev Immunol 2004, 4:499-511

43. Kawada N: The hepatic perisinusoidal stellate cell. Histol Histopathol 1997, 12:1069-1080

44. Friedman SL: Molecular regulation of hepatic fibrosis, an integrated cellular response to tissue injury. J Biol Chem 2000, 275:2247-2250

45. Paik YH, Schwabe RF, Bataller R, Russo MP, Jobin C, Brenner DA Toll-like receptor 4 mediates inflammatory signaling by bacterial lipopolysaccharide in human hepatic stellate cells. Hepatology 2003, 37:1043-1055

46. Seki E, De Minicis S, Osterreicher CH, Kluwe J, Osawa Y, Brenner DA Schwabe RF: TLR4 enhances TGF- $\beta$ signaling and hepatic fibrosis. Nat Med 2007, 13:1324-1332

47. Koruk M, Taysi S, Savas MC, Yilmaz O, Akcay F, Karakok M: Oxidative stress and enzymatic antioxidant status in patients with nonalcoholic steatohepatitis. Ann Clin Lab Sci 2004, 34:57-62

48. Nobili V, Pastore A, Gaeta LM, Tozzi G, Comparcola D, Sartorelli MR, Marcellini M, Bertini E, Piemonte F: Glutathione metabolism and an- 
tioxidant enzymes in patients affected by nonalcoholic steatohepatitis. Clin Chim Acta 2005, 355:105-111

49. Yesilova Z, Yaman H, Oktenli C, Ozcan A, Uygun A, Cakir E, Sanisoglu SY, Erdil A, Ates Y, Aslan M, Musabak U, Erbil MK, Karaeren N, Dagalp $\mathrm{K}$ : Systemic markers of lipid peroxidation and antioxidants in patients with nonalcoholic fatty liver disease. Am J Gastroenterol 2005, 100:850-855

50. Chalasani N, Deeg MA, Crabb DW: Systemic levels of lipid peroxidation and its metabolic and dietary correlates in patients with nonalcoholic steatohepatitis. Am J Gastroenterol 2004, 99:1497-1502

51. Akin K, Beyler AR, Kaya M, Erden E: The importance of iron and copper accumulation in the pathogenesis of non-alcoholic steatohepatitis. Turk J Gastroenterol 2003, 14:228-233

52. Machado MV, Ravasco P, Jesus L, Marques-Vidal P, Oliveira CR, Proenca T, Baldeiras I, Camilo ME, Cortez-Pinto H: Blood oxidative stress markers in non-alcoholic steatohepatitis and how it correlates with diet. Scand J Gastroenterol 2008, 43:95-102

53. Wake K: "Sternzellen" in the liver: perisinusoidal cells with special reference to storage of vitamin A. Am J Anat 1971, 132:429-462

54. Purohit V, Abdelmalek MF, Barve S, Benevenga NJ, Halsted CH, Kaplowitz N, Kharbanda KK, Liu QY, Lu SC, McClain CJ, Swanson C, Zakhari S: Role of S-adenosylmethionine, folate, and betaine in the treatment of alcoholic liver disease: summary of a symposium. Am J Clin Nutr 2007, 86:14-24

55. Martínez-Chantar ML, Vazquez-Chantada M, Ariz U, Martinez $N$, Varela M, Luka Z, Capdevila A, Rodriguez J, Aransay AM, Matthiesen R, Yang H, Calvisi DF, Esteller M, Fraga M, Lu SC, Wagner C, Mato JM: Loss of the glycine $\mathrm{N}$-methyltransferase gene leads to steatosis and hepatocellular carcinoma in mice. Hepatology 2008, 47:1191-1199

56. Wortham M, He L, Gyamfi M, Copple BL, Wan YJ: The transition from fatty liver to NASH associates with SAMe depletion in $\mathrm{db} / \mathrm{db}$ mice fed a methionine choline-deficient diet. Dig Dis Sci 2008, 53:2761-2774

57. Lu SC, Alvarez L, Huang ZZ, Chen L, An W, Corrales FJ, Avila MA Kanel G, Mato JM: Methionine adenosyltransferase 1A knockout mice are predisposed to liver injury and exhibit increased expression of genes involved in proliferation. Proc Natl Acad Sci USA 2001, 98:5560-5565

58. Mato JM, Lu SC: Role of S-adenosyl-L-methionine in liver health and injury. Hepatology 2007, 45:1306-1312

59. Park YM, Febbraio M, Silverstein RL: CD36 modulates migration of mouse and human macrophages in response to oxidized LDL and may contribute to macrophage trapping in the arterial intima. J Clin Invest 2009, 119:136-145

60. Bataller R, Schwabe RF, Choi YH, Yang L, Paik YH, Lindquist J, Qian T, Schoonhoven R, Hagedorn CH, Lemasters JJ, Brenner DA: NADPH oxidase signal transduces angiotensin II in hepatic stellate cells and is critical in hepatic fibrosis. J Clin Invest 2003, 112:1383-1394

61. Wheeler MD, Kono H, Yin M, Nakagami M, Uesugi T, Arteel GE, Gabele E, Rusyn I, Yamashina S, Froh M, Adachi Y, limuro Y, Bradford BU, Smutney OM, Connor HD, Mason RP, Goyert SM, Peters JM, Gonzalez FJ, Samulski RJ, Thurman RG: The role of Kupffer cell oxidant production in early ethanol-induced liver disease. Free Radic Biol Med 2001, 31:1544-1549

62. Rallidis LS, Drakoulis CK, Parasi AS: Pravastatin in patients with nonalcoholic steatohepatitis: results of a pilot study. Atherosclerosis 2004, 174:193-196

63. Hyogo H, Tazuma S, Arihiro K, Iwamoto K, Nabeshima Y, Inoue M, Ishitobi T, Nonaka M, Chayama K: Efficacy of atorvastatin for the treatment of nonalcoholic steatohepatitis with dyslipidemia. Metabolism 2008, 57:1711-1718 